\title{
Does Government Intervention in the Small-Firm Credit Market Help Economic Performance?
}




\section{Does Government Intervention in the Small-Firm Credit Market Help Economic Performance?}

By Ben R. Craig, William E. Jackson III, and James B. Thomson

The guaranteed lending programs of the Small Business Administration (SBA) are large and growing rapidly. The SBA's fiscal year 2008 performance budget calls for $\$ 25$ billion in guaranteed loans for small businesses-a new record for the agency. Some critics of SBA programs suggest they do not help small businesses or overall economic performance. Other critics suggest that these programs unfairly benefit the financial institutions that participate in SBA's guaranteed lending programs. While very little serious empirical evidence exists on whether the net economic impact of the SBA's guaranteed lending programs is positive or negative, a few recent studies provide some insight into the question. In general, they suggest a small positive impact of the SBA's programs on economic performance. However, the results are very tentative and further research is needed to declare a more definitive position. We provide a general overview of the SBA's guaranteed lending programs and summarize the results of these studies.

Ben R. Craig is an economic advsor at the Federal Reserve Bank of Cleveland. William E. Jackson III is professor of finance and management and the Smith Foundation Endowed Chair of Business Integrity in the Culverhouse College of Commerce at the University of Alabama. He is also a visiting research scholar at the Federal Reserve Bank of Atlanta. James B. Thomson is a vice president and economist at the Federal Reserve Bank of Cleveland. The authors thank Gerald Dwyer, Scott Frame, and Larry Wall for many valuable comments.

Materials may be reprinted, provided that the source is credited. Please send copies of reprinted materials to the editor.

Policy Discussion Papers are published by the Research Department of the Federal Reserve Bank of Cleveland.To receive copies or to be placed on the mailing list, e-mail your request to 4dsubscriptions@clev.frb.org or fax it to 216-579-3050. Please send your questions comments, and suggestions to us at editor@clev.frb.org.

Policy Discussion Papers are available on the Cleveland Fed's site on the World Wide Web: www.clevelandfed.org/Research.

Views stated in Policy Discussion Papers are those of the authors and not necessarily those of the Federal Reserve Bank of Cleveland or of the Board of Governors of the Federal Reserve System. 
Introduction

Federal loan guarantees provided by the U.S. Small Business Administration (SBA) have grown markedly in recent years. During fiscal year 2006, the SBA guaranteed a record $\$ 18$ billion in loans for small businesses-a 43 percent increase over the $\$ 12.6$ billion guaranteed for fiscal year 2003 (SBA 2007). Even more striking, the SBA expects to guarantee $\$ 25$ billion for the fiscal year 2008, representing a two-year growth rate of about 30 percent (SBA 2007). ${ }^{1}$

SBA loan guarantees are aimed at a segment of small business borrowers that presumably would not otherwise have access to credit. But the increase in SBA guaranteed lending has occurred at a time when the benefits of SBA guarantees should be declining.Advances in computer and communications technology have substantially reduced information costs to the economy, and technological innovation has improved the informational efficiency of credit markets-especially small business credit markets.

The recent growth of SBA loan guarantee programs, as well as their overall magnitude, raises questions as to whether there are demonstrable benefits to SBA activities and whether the benefits of the programs exceed their costs. Furthermore, because these programs represent society's decision to subsidize credit to promote small business in the United States, we should ask whether government loan guarantees are the best way to do this from a social welfare standpoint.To answer that question, we must know whether the subsidies are delivering their social benefits at the lowest social cost.

De Rugy (2007) argues that SBA guaranteed lending programs do not help small businesses or improve economic performance in the areas that receive these loans. She claims that SBA programs merely provide large subsidies for the financial institutions that participate in SBA's guaranteed lending programs.

It should be possible to empirically test for any signs of differential economic performance across local geographic markets based on the amount of SBA guaranteed loans flowing into those markets. SBA loan guarantee programs have been in existence for a substantial period of time, and they vary significantly in the amount of lending they channel into different geographic areas.

There are a few recent studies that do just that. They test for the impact of SBA guaranteed lending on economic performance, and they generally find a positive one. However, they also observe that their findings do not provide conclusive evidence that SBA guaranteed lending increases economic welfare. After all, SBA guaranteed lending programs provide subsidies either to lenders or borrowers or both, and we know that subsidies are not free. Someone must explicitly pay for them, and there may also be an implicit welfare cost.

We review these studies here and discuss their implications for public policy.We begin by sketching the economics of small business credit markets and the underlying eco- 
nomic mechanisms that might allow a directed subsidy such as SBA guaranteed lending to result in better observed economic performance before turning to the net welfare effect of SBA-administered subsidies.

\section{Small Business Credit Markets}

Lenders may fail to allocate loans efficiently because of information problems in the market for small business loans. For example, lenders may not be able to obtain reliable information concerning a potential borrower's ability to repay a loan. Information problems may be so severe that they lead to credit rationing and constitute a credit market failure. In Stiglitz and Weiss's (1981) classic analysis of credit market equilibrium in the presence of information frictions, banks consider both the interest rate they will receive on a loan and its riskiness when deciding to lend. However, in the presence of imperfect information, banks face two information effects that may cause the riskiness of the bank's loan portfolio to be affected by the bank's choice of a lending rate; this in turn, makes it unlikely that a rate will emerge that suits both the available buyers and sellers (that is, no interest rate will "clear the market"). One information effect, adverse selection, impedes the ability of markets to allocate credit using just the lending rate because it increases the proportion of high-risk borrowers in the pool of prospective borrowers. The other information effect, moral hazard, reduces the ability of rates alone to clear lending markets because once loan is extended the actions of borrowers is not independent of the lending rate.

Adverse selection is a consequence of an environment in which lenders can only observe the risk characteristics of a pool of borrowers but not those of any individual borrower. The inability of lenders to determine the risk characteristics of an individual borrower would not be a problem if loan applicants were drawn randomly from the borrower pool. In such a case, banks could post a loan rate that the reflected the risk of the average potential borrower. The bank could make a large number of small loans to borrowers in the pool, and the bank's loan portfolio would have the same risk and return characteristics as the pool of borrowers. Unfortunately, the willingness of a borrower to pay any posted lending rate is not independent of his risk. Borrowers who are willing to pay a higher interest rate are likely to be, on average, worse risks, since they are likely willing to borrow at a higher interest rate because they perceive their probability of repaying the loan to be lower. So, as the interest rate rises, the average "riskiness" of those who are willing to borrow increases-the adverse selection effect-and this may actually result in lowering the bank's expected profits from lending.

Moral hazard arises because the price a firm pays for credit can affect its investment decisions. Higher interest rates may induce firms to undertake riskier projects-projects with lower probabilities of success but higher payoffs when successful. Leveraged borrowers have more incentives to undertake risky projects than unleveraged ones. Simply 
raising the lending rate to account for lending-induced changes in firm risk-taking can be counterproductive, because a higher lending rate decreases the payoffs of successful projects to the firm.

As a result of adverse selection and moral hazard, a bank's expected return may increase less than proportionately with an additional increase in the interest rate, and beyond a certain point, may actually decrease as the interest rate increases. Clearly, it is conceivable that the demand for credit may exceed its supply in equilibrium. Although traditional analysis would argue that in the presence of an excess demand for credit, unsatisfied borrowers would offer to pay a higher interest rate to the bank, bidding up the interest rate until demand equals supply, it does not happen if market imperfections lead to adverse selection and moral hazard.This is because the bank will not lend to someone who offers to pay the higher interest rate, as this borrower is likely to be a worse risk than the average current borrower. The expected return on a loan to a borrower at the higher interest rate may be actually lower than the expected return on loans the bank is currently making. In such an environment, there are no market forces leading supply to equal demand, and credit is rationed.

\section{Lending Relationships as a Partial Antidote to Credit Rationing}

Lending relationships have been recognized by economists as an important market mechanism for reducing credit rationing. ${ }^{2}$ Lending is based on limited information on the quality of borrowers in the market, but a close and continued interaction between a firm and a bank may provide a lender with sufficient information about, and a voice in, the firm's affairs so as to lower the cost and increase the availability of credit. Conditional on its positive past experience with the borrower, the bank may expect future loans to be less risky, which should reduce its average cost of lending and increase its willingness to provide funds.

The relationship-lending literature suggests that in addition to being formed over time, relationships can be built through interaction over multiple products. That is, borrowers may obtain more than just loans from a bank. Borrowers may purchase a variety of financial services such as checking and savings accounts. These added dimensions of a relationship can affect the firm's borrowing cost in two ways. First, they increase the precision of the lender's information about the borrower. For example, the lender can learn about the firm's sales by monitoring the cash flowing through its checking account or by factoring in the firm's accounts receivable. Second, the lender can spread any fixed costs of monitoring the firm over multiple products.

Overall, the available evidence indicates that the strength and duration of lending relationships are significantly correlated with both the terms (lower loan rates and fewer loan covenants) and the availability of credit. From the perspective of the banks, the

2. See, for example, Kane and Malkiel (1965), Petersen and Rajan (1994), Berger and Udell (1995), and Stein (2002). 
stronger the relationship, the more likely the borrower is to select the bank for future credit needs and other banking services.

The Potential Role for SBA Loan Guarantees

Ensuring access to credit has been an important pillar of public support for small business in the United States for more than half a century. ${ }^{3}$ Concerns that small firms may face problems in getting access to funding may be valid, as a large share of small firms are relatively young and have little or no credit history. Lenders may be reluctant to fund small firms, especially those with new and innovative products, which are likely difficult to evaluate. If small businesses face severe credit rationing, they may become credit constrained and miss out on projects that have a positive net present value because they cannot raise the external capital necessary to fund them. This possibility suggests that to the extent credit rationing significantly affects small business credit markets, a rationale exists for supporting small enterprises through government programs aimed at improving their access to credit.

\section{How Can SBA Loan Guarantees Reduce Credit Rationing?}

Loan guarantees are one mechanism that can be used to mitigate credit rationing by providing a mechanism for pricing loans that is independent of borrower behavior. By reducing the expected loss if the borrower defaults on the loan, the guarantee increases the lender's expected return-without increasing the lending rate. With the guarantee in place, lenders could profitably extend credit at loan rates below what would be dictated by the risk of the average borrower. Hence, loan guarantees lessen the adverse selection problem, as the lower interest rate increases the share of loan applications from lowerrisk borrowers, increasing the likelihood that the risk characteristics of the bank's loan portfolio increasingly approximate that of the borrowing pool. Moreover, the guarantee increases the profitability of the loan by reducing the losses to the bank in those instances when the borrower defaults.

To the extent that the loan guarantees reduce the rate of interest at which banks are willing to lend, external loan guarantees will also help mitigate the moral hazard problem.This is because the lower lending rates afforded by external guarantees reduce the bankruptcy threshold and thereby increase the expected return of safe projects vis-à-vis riskier ones.

Thus, in theory, SBA loan guarantees should reduce the probability that a viable small business is credit rationed. And because the program reduces the risk to the lender of establishing a relationship with informationally opaque small business borrowers, it may also increase the prospect of relationship-based loans in the future. Finally, the SBA loan guarantee programs may improve the intermediation process by lowering the risk to the
3. Public support for small enterprise appears to be based on the widely held perception that the small business sector is an incubator of economic growth-a place where innovation takes place and new ideas become economically viable business enterprises. In addition, policymakers routinely point to small businesses as important sources of employment growth. Possibly as a result, there is widespread political support for government programs, tax breaks, and other subsidies aimed at encouraging the growth and development of small business in the United States, and increasingly, around the world (Bergström, 2000). 
lender of extending longer-term loans, ones that more closely meet the needs of small businesses for capital investment.

It is interesting to note that small-firm credit markets are becoming better at addressing some of the problems SBA guarantees are intended to address. For example, credit-scoring technology may help alleviate some credit rationing. As discussed in Berger and Frame (2006), small-business credit scoring is a lending technology used by many financial institutions over the last decade to evaluate applicants for "micro credits," those under $\$ 250,000$. The credit-scoring technology analyzes consumer data about the owner of the firm and combines it with relatively limited data about the firm itself using statistical methods to predict future credit performance. As these markets develop and more financial institutions engage in these lending technologies, the degree to which small businesses face credit rationing may decline, which suggests that the value of SBA guaranteed lending may decline as well; at least to the extent that small-business credit scoring reduces frictions in the small-firm credit market. ${ }^{4}$

One should not jump to the conclusion that the presence of a market imperfection, in this case a credit market friction, means that government intervention to correct it is desirable. The SBA's loan guarantee programs, for example, selectively influence credit allocation by guaranteeing the loans of a certain class of small enterprises. From Kane (1977) and Craig and Thomson (2003), we know that selective credit allocation is likely to be an inefficient and possibly counterproductive policy tool. In the case of financial institutions, the provision of subsidies tied to small-enterprise lending is likely to have costly unintended effects. The welfare costs of these unintended consequences may include deadweight losses associated with resource misallocation, wealth redistribution, and the possible reduced stability of the banking system. In the case of small businesses, the provision of subsidies tied to borrowing is likely to increase the amount of debt capital held by small firms and produce any resultant welfare costs associated with this differing capital structure. The subsidy associated with SBA guaranteed lending may have redistributional effects that are inconsistent with conventional notions of social welfare. For example, it is likely that most of the wealth transfer will go to established small business owners or to the shareholders of the lending institutions, neither of which represents the poorest or most disadvantaged groups in our society. ${ }^{5}$

Nonetheless, the net value of subsidizing small businesses will be positive if the benefits are greater than the costs. One of these benefits may be an increase in local market employment rates. This employment increase may have significant social benefits, especially in areas with chronic levels of low employment.

\section{SBA Loan Guarantee Programs and Local Economic Performance}

The Small Business Administration was born on July 30, 1953. The SBA received most of its powers from two agencies that were dissolved at its birth. These agencies were the
4. For more on credit scoring as a lending technology see: Berger and Frame (2006); Berger, Frame, and Miller (2005); Frame and Woolsey (2001); Frame, Padhi, and Woolsey (2004).

5. See Craig and Thomson (2003) for more on this point. 
Reconstruction Finance Corporation (RFC) and the Small Defense Plants Agency (SDPA). The SBA received the authority to make direct loans and guarantee bank loans to small businesses from the RFC. It was also assigned the RFC's role of making loans to victims of natural disasters. From the SDPA, the SBA received the authority to help small businesses procure government contracts and to help small business owners by providing managerial, technical, and businesses training assistance.

Recognizing that private financial institutions are typically better than government agencies at deciding on which small business loans to underwrite, the SBA began moving away from making direct loans and toward guaranteeing private loans in the mid-1980s. Currently, the SBA makes direct loans only under very special circumstances. Guaranteed lending through the SBA's 7(a) guaranteed loan program and the 504 loan program are the main form of SBA activity in lending markets.

The more basic and more significant of these two programs is the 7(a) loan program. The program's name refers to Section 7(a) of the Small Business Act, which authorizes the agency to provide business loans to small businesses. All 7(a) loans are provided by commercial lenders. A very large percentage of American commercial banks participate in the 7 (a) program, as do a number of finance companies, credit card banks, and other nonbank lenders.

It is important to note that 7(a) loans are made available only on a guarantee basis. This means that they are provided by lenders who choose to structure their own loans in accordance with SBA's underwriting requirements and then apply for and receive a guarantee from the SBA on a portion of the loan.The SBA does not guarantee the full amount of a 7 (a) loan but rather usually about 50 to 85 percent of it. The maximum 7(a) loan is $\$ 2,000,000$ and the maximum guarantee on that loan is $\$ 1,500,000$ (SBA 2007). Because the SBA guarantees only part of the full amount of these loans, the lender and the SBA share the risk that a borrower will not repay them in full.

The 504 loan program is a long-term financing tool for economic development within a community.The 504 program provides growing businesses with long-term, fixed-rate financing for major fixed assets, such as land or buildings, through a certified development company (CDC).A CDC is a nonprofit corporation set up to contribute to the economic development of its community. CDCs work with the SBA and private-sector lenders to provide financing to small businesses. There are about 270 CDCs nationwide. Each CDC covers a specific geographic area (SBA 2007).

Typically, a 504 project includes a loan from a private-sector lender, which covers up to 50 percent of the project cost, a loan from the CDC (backed by a 100 percent SBAguaranteed debenture) covering up to 40 percent of the cost, and a contribution of at least 10 percent equity from the small business being helped.The SBA-backed loan from the $\mathrm{CDC}$ is usually subordinate to the private loan, which has the effect of insulating the 
private lender from loss in the event of default. (For more on the 504 or 7 (a) programs see SBA, 2007.)

If SBA loan guarantees reduce credit rationing in the markets for small business loans, there should be a relationship between measures of SBA guaranteed lending activities and economic performance. We are thinking here primarily in terms of credit market frictions in the form of costly information acquisition and project verification, which can lead to lower levels of credit allocation that negatively impact economic performance in the local market. ${ }^{6}$ To the extent that SBA's guaranteed lending program mitigates such credit market frictions, there should be a positive relationship between the amount of SBA guaranteed lending and economic performance, especially across local markets where credit market frictions are likely to be a significant problem. ${ }^{7}$

\section{Recent Empirical Literature}

Does more SBA guaranteed lending lead to higher levels of local market economic performance? A search of the economic literature since 1990 on this question found only three papers-two of those by the authors of this article - that attempt to address it. We review those papers here.

The results from Craig, Jackson, and Thomson (2007b) suggest that the answer to our question is yes; SBA guaranteed lending does lead to higher levels of local market economic performance. In that paper we empirically test whether SBA guaranteed lending has a greater impact on economic performance in low-income markets. This hypothesis is predicated on priors related to four overlapping assumptions. These four assumptions are: (1) income levels proxy for relative development of the local financial markets, (2) less developed financial markets are more likely to have more severe information asymmetry problems, and thus are more likely to be impeded by credit rationing problems (Stiglitz and Weiss, 1981), (3) SBA guaranteed lending is likely to reduce these credit rationing problems-thus, improving the level of development of that local financial market, and (4) increased financial development helps to lubricate the wheels of economic performance (Rajan and Zingales, 1998).

Using local labor market employment rates as our measure of economic performance, we find evidence consistent with this proposition. In particular, we find a positive and significant correlation between the average annual level of employment in a local market and the level of SBA guaranteed lending in that local market. And the intensity of this correlation is relatively larger in low-income markets. Indeed, one interpretation of our results is that this correlation is positive and significant only in low-income markets.

In Craig, Jackson, and Thomson (2007a) we report regression results that are consistent with the hypothesis that SBA guaranteed lending produces positive, albeit small, net social benefits. Specifically, we report consistent evidence that the level of SBA-guaranteed lending activity (per $\$ 1000$ of deposits) is positively related to the growth of per
6. An implicit assumption here is that labor and capital are complements...at least for small firms.

7. This empirical relationship is also supported by the economics literature that documents a significant positive correlation between economic growth and financial market development. This literature dates at least to the controversial studies of Schumpeter (1911) and Robinson (1952). More recent important studies that provide evidence that relatively higher levels of financial market development tend to lead to higher levels of economic performance include King and Levine (1993a, 1993b), Jayaratne and Strahan (1996), Rajan and Zingales (1998), and Guiso, Sapienza, and Zingales (2004). 
capita income at the local market level—for both urban and rural markets. The impact of SBA-guaranteed lending on growth appears to be small. However, this small measurable economic impact of SBA loan guarantees on local economic growth would be expected given the limited role they play in the overall (small and large firm) credit intermediation process.

In Craig, Jackson, and Thomson (2007a), our sample consists of local economic markets for which we have complete SBA guaranteed lending data over the sample estimation period (1992 through 2001). Our sample contained more than 360,000 SBA loans aggregated to the local market level for each year in our sample. We estimated our models separately for urban and rural markets (that is, MSA and non-MSA counties, respectively). We used the instrumental variables (with the instruments from prior periods) and meantransformed data in our estimation procedures.

The results from both Craig, Jackson, and Thomson (2007a) and Craig, Jackson, and Thomson (2007b) should be interpreted with caution, however, for at least two reasons. First, we are unable to control for small-business lending at the local market level, so we do not know whether SBA 7(a) loan guarantees are contributing to economic performance by helping to complete the market for small firm credit or whether they are simply proxying for small business lending in the market. Second, we are not able to test whether SBA loan guarantees materially increase the volume of small business lending in a market-a question that is related to who captures the subsidy associated with SBA loan guarantees. In other words, simply finding a positive correlation between measures of SBA guarantees and local economic performance is only the first step towards establishing the desirability of these programs. More evidence is needed to establish that SBA guaranteed lending programs are welfare enhancing.

Rappaport and Wyatt (1990) investigate the effects of bank characteristics and market demographics on bank participation in SBA lending.They find that banks that participate more intensively in SBA lending concentrate more on business lending, are more likely to be members of a holding company, and may substitute SBA loans for consumer loans secured by personal assets in markets with populations of 50,000 or less. They also find that in local markets with a population of 50,000 or less, greater SBA lending is associated with lower per capita income levels. They surmise that this correlation may be because the SBA has achieved its economic development policy objective, which is to focus more on low-income rural market areas.

\section{The Performance of SBA-Guaranteed Loans}

Glennon and Nigro (2005) examine the loan performance of small firms receiving SBAguaranteed loans. They place the performance history of SBA loans into perspective by comparing their default experience to that of rated corporate bonds. They find that the 
historical cumulative default rates of SBA-guaranteed loans fall between the $\mathrm{Ba} / \mathrm{BB}$ and $\mathrm{B}$ rated corporate-bond grades as reported by Moody's and S\&P.Although as a group, SBA loans are below investment grade, this historical behavior places them in the upper end of the speculative grade category and of similar credit quality as a large percentage of loans held by large commercial banks.

Unlike previous research, Glennon and Nigro find that the hazard of default for SBA loans is conditional on several key borrower, lender, and loan characteristics. More specifically, they find that loans to new businesses have a greater hazard of default than established firms. They also find, surprisingly, that larger SBA-qualified firms (measured by the number of employees at time of loan origination) experience a greater hazard of default than smaller ones.

As might be expected, they find that SBA-specialized lender programs (i.e., certified lender program and preferred lenders program) have lower hazard rates than the SBA's regular lender programs. They also find that loans with higher guarantee percentages are associated with a greater hazard of default. This result is consistent with agency theory, which would explain that lenders with less at stake on a loan have less incentive to monitor that loan.The SBA has been addressing this issue by lowering the maximum guarantee percentage over the past decade.

Finally, Glennon and Nigro also identify an important link between both regional and industry economic conditions and the likelihood of loan default. Similar to previous research on other loan types, they find that the success and failure of small-business loans are closely tied to the regional and industry-specific economic conditions in which the borrower operates.

\section{Conclusion}

The SBA's guaranteed lending programs are large and growing rapidly. Some suggest these programs are useless for helping small businesses or improving economic performance in the areas that receive these loans. Others insist the programs are needed to provide support to small businesses, which often face difficulties finding sufficient borrowing opportunities.

However, very little serious empirical evidence exists on whether the net economic impact of SBA's guaranteed lending programs is positive or negative.A few recent studies provide some insight for considering this question. In general, they provide evidence consistent with a likely small positive impact of SBA's guaranteed lending programs on economic performance. However, these results are very tentative and much more research is needed to declare a more definitive position. Nonetheless, it appears that the preponderance of the evidence from the current economics literature neither provides a strong case against nor a strong case for continuing the SBA's guaranteed lending programs. 


\section{References}

Bergström, Fredrik. 2000. "Capital Subsidies and the Performance of Firms," Small Business Economics, vol. 14, no. 3, pp. 183-93.

Berger,Allen N.,W. Scott Frame, and Nathan Miller. 2005."Credit Scoring and the Availability, Price, and Risk of Small Business Credit," Journal of Money, Credit, and Banking, vol. 37, pp. 191-222.

Berger,Allen N., and W. Scott Frame. 2006."Small Business Credit Scoring and Credit Availability, Journal of Small Business Management, forthcoming.

Berger,Allen N., and Gregory F. Udell. 1995. "Relationship Lending and Lines of Credit in Small Firm Finance," Journal of Business, vol. 68, no. 3, pp. 351-81.

Craig, Ben R.,William E.Jackson, III, and James B.Thomson. 2004."Are SBA Loan Guarantees Desirable?" Federal Reserve Bank of Cleveland, Economic Commentary (September 15).

Craig, Ben R., William E. Jackson, III, and James B.Thomson. 2005. "The Role of Relationships in Small-Business Lending," Federal Reserve Bank of Cleveland, Economic Commen$\operatorname{tary}$ (October 15).

Craig, Ben R., William E. Jackson, III, and James B. Thomson. 2006. "On SBA Guaranteed Lending and Economic Growth," Economic Development through Entrepreneurship: Government, University, and Business Linkages (New Horizons in Entrepreneurship), Edward Elgar Publishing, pp. 127-50.

Craig, Ben R., William E. Jackson, III, and James B.Thomson. 2007a."SBA-Loan Guarantees and Local Economic Growth, Journal of Small Business Management, vol. 45, pp. 116-32.

Craig, Ben R.,William E. Jackson, III, and James B.Thomson. 2007b. "Credit Market Failure Intervention: Do Government-Sponsored Small Business Credit Programs Enrich Poorer Areas?" Small Business Economics, forthcoming. DOI 10.1007/s11187-007-9050-5.

Craig, Ben R., William E. Jackson, III, and James B. Thomson. 2007c. "Small-Firm Credit Market Discrimination," SBA Guaranteed Lending, and Local Market Economic Performance. Annals of the American Academy of Political and Social Science, forthcoming.

Craig, Ben R., and James B.Thomson. 2003."Federal Home Loan Bank Lending to Community Banks: Are Targeted Subsidies Desirable?” Journal of Financial Services Research, vol. 23, no. 1, pp. 5-28. 
De Rugy, Veronique. 2007. “The SBA's Justification IOU.” American Enterprise Institute, Regulation, Spring, 26-34.

Frame,W.Scott,Aruna Srinivasan, and Lynn Woosley. 2001."The Effect of Credit Scoring on Small Business Lending," Journal of Money, Credit, and Banking, vol.33, pp.813-25.

Frame, W. Scott, Michael Padhi, and Lynn Woolsey. 2004."The Effect of Credit Scoring on Small Business Lending in Low- and Moderate Income Areas," Financial Review, vol. 39, pp. 35-54.

Glennon, Dennis, and Peter Nigro. 2005a. "An Analysis of SBA Loan Defaults by Maturity Structure,"Journal of Financial Services Research, vol. 28, pp. 77-111.

Guiso, Luigi, Paola Sapienza, and Luigi Zingales. 2004."Does Local Financial Development Matter?" Quarterly Journal of Economics, vol. 119, pp. 929-69.

Jayartne, Jith and Philip E.Strahan. 1996."The Finance-Growth Nexus: Evidence from Bank Branch Deregulation," Quarterly Journal of Economics, vol. 111, no. 3, pp. 639-70.

Kane, Edward J., and Burton G. Malkiel. 1965."Bank Portfolio Allocation, Deposit Variability, and the Availability Doctrine," Quarterly Journal of Economics, vol. 79, no. 1, pp. 113-34.

Kane, Edward J. 1977. "Good Intentions and Unintended Evil:The Case against Selective Credit Allocation," Journal of Money, Credit, and Banking, vol. 9, no. 1, pp. 55-69.

King, Robert G., and Ross Levine. 1993a. "Finance and Growth: Schumpeter Might Be Right," Quarterly Journal of Economics, vol. 108, no. 3, pp. 717-37.

King, Robert G., and Ross Levine. 1993b."Finance, Entrepreneurship, and Growth:Theory and Evidence,"Journal of Monetary Economics, vol. 32, no. 3, pp. 513-42.

Myers, Stewart C., and Nicholas S. Majluf. 1984."Corporate Financing and Investment Decisions when Firms Have Information that Investors Do Not Have,"Journal of Financial Economics, vol. 13, pp. 187-221.

Petersen, Mitchell, A., and Raghuram G. Rajan. 1994. "The Benefits of Lending Relationships: Evidence from Small Business Data,'Journal of Finance, vol. 49, no. 1, pp. 3-37.

Rajan, Raghuram, G. and Luigi Zingales. 1998."Financial Dependence and Growth," American Economic Review, vol. 88, no. 3, pp. 559-86. 
Rappaport Allen, and Robert W.Wyatt. 1990. "Some Policy Implications of Bank Participation in Small Business Administration Lending Programs," Small Business Economics, vol. 2,pp. 155-62.

Robinson, Joan. 1952. The Generalization of the General Theory: The Rate of Interest and Other Essays. London, U.K.: Macmillan Press.

Small Business Administration. 2005. "Small and Micro Business Lending for 2003-2004," U.S. Small Business Administration, Office of Advocacy, November 2005, Report No. 266.

Small Business Administration. 2007. Home Page. <www.sba.gov> Accessed May 2007.

Schumpeter, Joseph. 1911. A Theory of Economic Development. Cambridge, Mass.: Harvard University Press.

Stiglitz, Joseph E., and Andrew Weiss. 1981. "Credit Rationing in Markets with Imperfect Information," American Economic Review, vol. 71, no. 3, pp.393-410.

White, Lawrence J. 1982.The Determinants of the Relative Importance of Small Business," Review of Economics and Statistics, vol. 64, no. 1, pp. 42-9. 


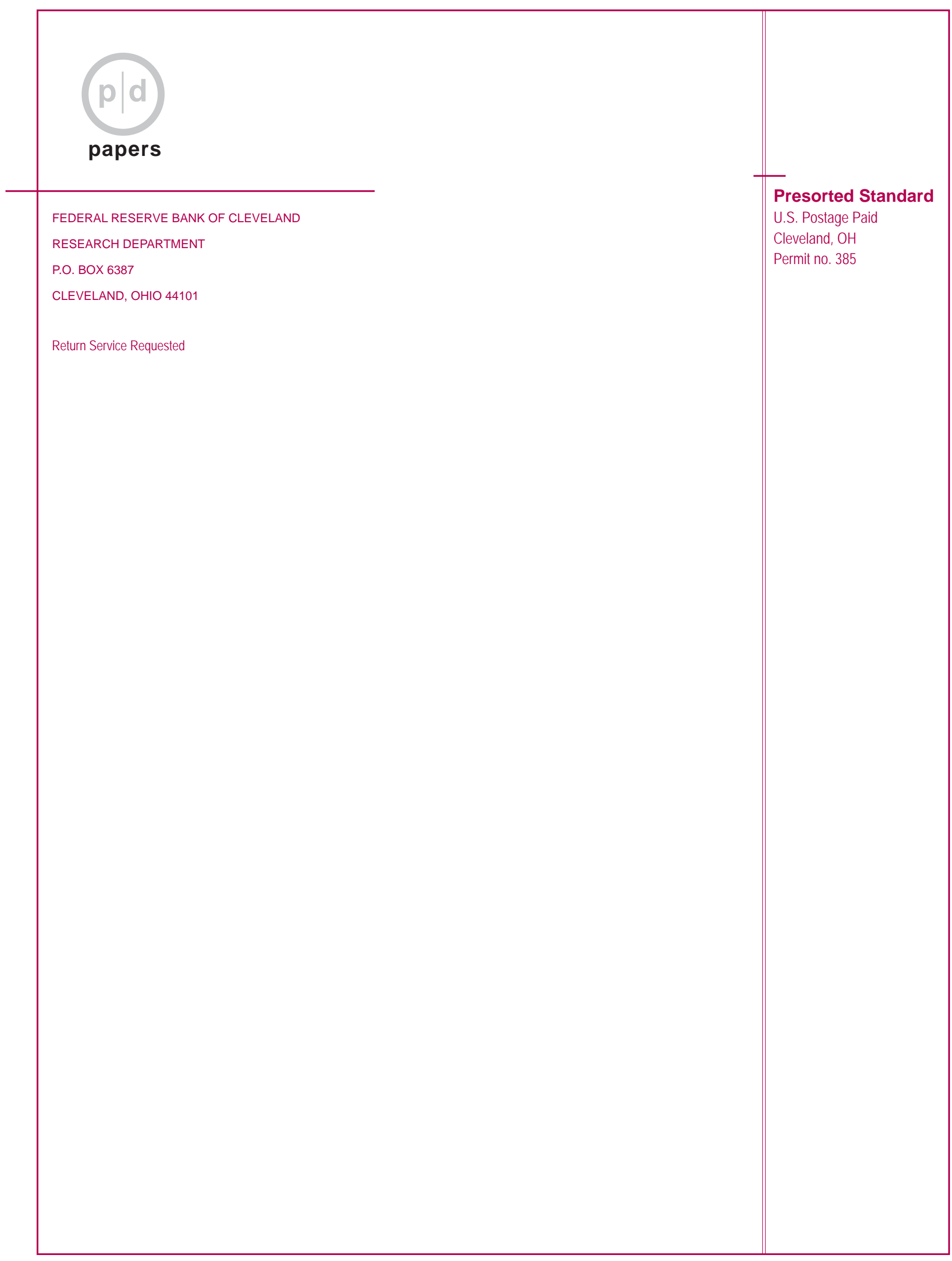

